\title{
Corporate crime does pay! The Relationship between Financial Crime and Imprisonment in White-Collar Crime
}

\author{
Petter Gottschalk ${ }^{1, *}$, Lars Glas $\varnothing^{1,2, * *}$ \\ 1Department of Leadership and Organizational Management, BI Norwegian Business School, \\ Nydalsveien 37, Oslo 0484, Norway \\ 2Department of Psychosocial Science, Faculty of Psychology, University of Bergen, \\ Christiesgt. 12, Bergen 5020, Norway \\ *,**Email address: petter.gottschalk@bi.no , lars.glaso@bi.no
}

\begin{abstract}
White-collar crime is financial crime committed by white-collar criminals. Sensational whitecollar crime cases regularly appear in the international business press and studies in journals of ethics and crime. Many of these scholars apply anecdotal evidence to suggest what might be included and what might be excluded from the concepts of white-collar crime and white-collar criminals. On contrast, with a larger sample, we can study white-collar crime convictions using statistical techniques to identify relationships between variables. For example, it has been suggested that the amount involved in the crime (fraud, corruption, etc.) is an important factor when the judge decides the length of the prison sentence. In our sample of 255 criminal cases we identified 88 corporate criminals and 167 occupational criminals. Age when convicted was 47 years for occupational criminals and 49 years for corporate criminals. Furthermore, occupational criminals served 2.2 years in prison, while corporate criminals served only 2.1 years. This is particularly interesting, when the amount of money that was involved in the crime is taken into account. While occupational criminals on average abused 26 million Norwegian kroner, corporate criminals on average abused as much as 121 million Norwegian kroner. So, even if the magnitude of the financial crime in terms of money was substantially and significantly larger for corporate crime, occupational crime was nevertheless judged more severely in terms of imprisonment.
\end{abstract}

Keywords: Financial crime; white-collar criminal; empirical study; prison; corporate crime

\section{INTRODUCTION}

White-collar crime is financial crime committed by white-collar criminals. Sensational white-collar crime cases regularly appear in the international business press and studies in journals of ethics and crime. White-collar crime is financial crime committed by upper class members of society for personal or organizational gain. White-collar criminals are individuals who tend to be wealthy, highly educated, and socially connected, and they are typically employed by, and in, legitimate organizations. Ever since Edwin Sutherland introduced the concept of "white-collar" crime in 1939, researchers have discussed what might be encompassed by this concept and what might be excluded. The discussion is summarized by 
scholars such as Benson and Simpson (2009), Blickle et al. (2006), Bookman (2008), Brightman (2009), Bucy et al. (2008), Eicher (2009), Garoupa (2007), Hansen (2009), Heath (2008), Kempa (2010), McKay et al. (2010), Pickett and Pickett (2002), Podgot (2007), Robson (2010), Schnatterly (2003) and Gottschalk \& Glasø (2013).

Most of these scholars apply anecdotal evidence to suggest what might be included and what might be excluded from the concepts of white-collar crime and white-collar criminals. Examples of anecdotal evidence in the United States are famous white-collar criminals such as Bernard Madoff, Raj Rajaratnam and Jeffrey K. Skilling. While being relevant and interesting case studies, the extent of generalization from such case studies applied by some of the scholars mentioned above is questionable. What seems to be needed is a larger sample of white-collar criminals that can be studied in terms of average values as well as variation in white-collar characteristics. Moreover, with a larger sample, we can study white-collar crime convictions using statistical techniques to identify and study groups of white-collar criminals. In this respect, the present article is concerned with the following research question: What differences can be found between occupational and corporate white-collar criminals?

\section{LITERATURE REVIEW}

Bookman (2008) regards Sutherland's (1949) original definition of white-collar crime as too restrictive and suggests that white-collar crime is an illegal act committed by nonphysical means and by concealment or guile, to obtain money or property, to avoid payment or loss of money or property, or to obtain business or personal advantage. Furthermore, scholars have attempted to differentiate white-collar crime into two types: occupational and corporate. By and large, individuals or small groups in connection with their jobs commit occupational crime. This includes embezzlement from an employer, theft of merchandise, income tax evasion, and manipulation of sales, fraud, and violations in the sale of securities. Corporate crime, on the other hand, is enacted by collectivities or aggregates of discrete individuals.

According to Hansen (2009), individuals or groups commit occupational or elite crime for their own purposes or enrichment, rather than for the enrichment of the organization on a whole, in spite of supposed corporate loyalty.

White-collar crime occurs typically at higher levels in business. It is crime committed by a corporate manager, a high-ranking technical specialist, a procurement manager, an official representative of a corporation, or the owner of a corporation. Included in this term are both the possibility that the white-collar offender acted self-servingly to further private interests or the interests of a group of persons in a corporation that is typically labeled occupational crime, and the possibility that the person may have acted on behalf of the corporation with the intention of protecting or enhancing the interests of the corporation (Blickle et al., 2006).

A distinction can be made between occupational crime and corporate crime. Occupational crime is sometimes labeled elite crime. Hansen (2009) argues that the problem with occupational crime is that it is committed within the confines of positions of trust and in organizations, which prohibits surveillance and accountability. Heath (2008) found that the bigger and more severe occupational crime tends to be committed by individuals who are further up the chain of command in the firm.

If a corporate official violates the law in acting for the corporation then this is also considered a corporate crime. But if he or she gains personal benefit in the commission of a 
crime against the corporation, it is classed as occupational crime. A corporation cannot be jailed, and therefore, the majority of penalties to control individual violators are not available for corporations and corporate crime (Bookman, 2008). Simpson (2011) argues that thinking about corporate crime requires recognition that both organizations and individuals may be illegal actors and potential targets for crime prevention and control such as sanctions.

Corporate crime occurs when, for example, fraud is being committed on behalf of an organization; that is the crime is being committed to benefit the business. Other crimes would be classified as against an organization, e.g. occupational fraud. Perri and Brody (2011) argue that corporate crime is rationalized as a behavior acceptable to overcome financial difficulties or to make a profit for the business, while occupational crime is rationalized in other ways: I am borrowing the money and will pay it back, or the company owes me money that I never received, but deserve. Fleet and Fleet (2006) argue that corporate crime is committed by higher ranking officers:

Corporate crime refers to those crimes committed by members of an organization to benefit the organization. White-collar crime refers to those crimes committed by higher-ranking members of an organization to benefit themselves. Occupational or employee crime refers to those crimes committed by members of an organization (generally lower ranking) that are intended to benefit the perpetrators to the detriment of the organization.

In legal terms, a corporation is an unnatural person (Robson, 2010: 109):

Corporate personality functions between an insentient, inanimate object and a direct manifestation of the acts and intentions of its managers. Nowhere is this duality more problematic than in the application of traditional concepts of criminal law to business organizations. The question of whether business organizations can be criminally liable - and if so, the parameters of such liability - has long been the subject of scholarly debate. Whatever the merits of such debate, however, pragmatic considerations have led courts and legislatures to expand the panoply of corporate crime in order to deter conduct ranging from reprehensible, to undesirable, to merely annoying. In the context of organizational behavior, criminal law is the ultimate deterrent.

Corporations become victims of crime when they suffer a loss as a result of an offense committed by a third party, including employees and managers. Corporations become perpetrators of crime when managers or employees commit financial crime within the context of a legal organization. According to Garoupa (2007), corporations can more easily corrupt enforcers, regulators and judges, as compared to individuals. Corporations are better organized, are wealthier and benefit from economies of scale in corruption. Corporations are better placed to manipulate politicians and the media. By making use of large grants, generous campaign contributions and influential lobbying organizations, they may push law changes and legal reforms that benefit their illegal activities.

Occupational crime is typically motivated by greed, where white-collar criminals seek to enrich themselves personally. Similarly, firms engage in corporate crime to improve their financial performance. Employees break the law in ways that enhance the profits of the firm, but which may generate very little or no personal benefit for themselves when committing corporate crime (Heath, 2008: 600):

There is an important difference, for instance, between the crimes committed at Enron by Andrew Fastow, who secretly enriched himself at the expense of the firm, and 
those committed by Kenneth Lay and Jeffrey Skilling, who for the most part acted in ways that enriched the firm, and themselves only indirectly (via high stock price).

While legal corporations may commit business crime, illegal organizations are in the business of committing crime. Garoupa (2007) emphasized the following differences between organized crime and business crime (i) organized crime is carried out by illegal firms (with no legal status), the criminal market being their primary market and legitimate markets secondary markets, (ii) corporate crime is carried out by legal firms (with legal status), the legitimate market being their primary market and the criminal market their secondary market. Whereas organized crime exists to capitalize on criminal rents and illegal activities, corporations do not exist to violate the law. Organized crime gets into legitimate markets in order to improve its standing on the criminal market, while corporations violate the law so as to improve their standing on legitimate markets.

Criminal opportunities are now recognized as an important cause of all crime. Without an opportunity, there cannot be a crime. Opportunities are important causes of white-collar crime, where the opportunity structures may be different from those of other kinds of crime. These differences create special difficulties for control, but they also provide new openings for control (Benson and Simpson, 2009).

While occupational crime is associated with bad apples, corporate crime is associated with systems failure. Bad apples theory represents an individualistic approach in criminology, while systems failure theory represents a business approach in criminology (Heath, 2008: 601):

If the individualistic approach were correct, then one would expect to find a fairly random distribution of white collar crime throughout various sectors of the economy, depending upon where individuals suffering from poor character or excess greed wound up working. Yet, what one finds instead are very high concentrations of criminal activity in particular sectors of the economy. Furthermore, these pockets of crime often persist quite stubbornly over time, despite a complete changeover in the personnel involved.

Similar to the distinction between corporate and occupational crime is the distinction made by Simpson (2011) between those kinds of crime committed by companies and their managers to achieve the goals of the business, and offenses committed by individuals that may or may not involve organizational or business resources, but tend to be tied more to selfinterest.

\section{CRIME THEORIES}

Institutional theory of morale collapse might explain the extent of corporate crime. Executives in a deteriorating business will tend to expand both occupational crime and corporate crime to make profit both personally and for the business. This is caused by moral collapse as a consequence of business collapse. The sequence might be that corporate crime occurs ahead of occupational crime.

Shadnam and Lawrence (2011: 379) applied institutional theory to explain moral decline and crime potential in organizations:

Our theory of moral collapse has two main elements. First, we argue that morality in organizations is embedded in nested systems of individuals, organizations and moral 
communities in which ideology and regulation flow "down" from moral communities through organizations to individuals, and moral ideas and influence flow "upward" from individuals through organizations to moral communities. Second, we argue that moral collapse is associated with breakdowns in these flows, and explore conditions under which such breakdowns are likely to occur.

Shadman and Lawrence (2011: 393) formulated several research hypotheses, which imply that the likelihood of moral decline will vary depending on several circumstances:

- Moral collapse is more likely to happen in organizations that operate in moral communities in which flows of ideology are disrupted, either through a lack of commitment to formal communication mechanisms by community leaders or the disruption of informal communication networks by high rates of membership turnover.

- Moral collapse is more likely to happen in organizations in which structures and practices diminish the organization's capacity to absorb and incorporate morally charged institutions from the organization's moral community, because the organization monopolizes the attention of its members and/or because the organization delegitimizes the morally charged institutions rooted in the moral community.

- Moral collapse is more likely to happen in organizations in which accusing individuals of misconduct creates significant social and economic costs for the organization or the moral community within which it operates.

- Moral collapse is more likely to occur in organizations to the degree that employment conditions undermine enclosure and/or work arrangements diminish the effectiveness of surveillance.

Institutional theory is in line with dysfunctional network theory in that organizations tend to mirror the basic elements of their environments. The largest business corporations can more easily absorb the negative impact of legal sanctions that some governmental or regulatory agencies might impose on them. The largest business enterprises might have better lawyers and other resources, so that they can face legal pursuits in more effective and efficient ways. Microsoft versus the United States and Microsoft versus the European Union are typical examples. Therefore, laws and regulations tend to have a much less deterrent effect in the case of large business organizations (Dion, 2009). As a consequence, and ceteris paribus, it might be suggested based on this theory that larger organization more easily can survive corporate crime.

Self-control theory can explain a greater impact on occupational versus corporate crime. The lower the individual's self-control, the greater is the likelihood of his or hers involvement in criminal behavior. Low self-control is defined in terms of characteristics such as impulsive, risk-taking, and self-centered (Meneses and Akers, 2011). Thus, self-control theory proposes that individuals commit crime because of low self-control. Except in rare cases of mass fraud such as the Enron scandal, not all the elite within a given organization or industry will commit crime. Hence, although the elite at the top of their profession and corporation differentially associate with people of equal status in their own and other corporations, not all corporate elites commit crimes and behave in an overtly deviant manner (Hansen, 2009).

Gross (1978) argued in his classical article on the theory of organizational crime that a considerable number of areas of sociology, studies of crime and delinquency usually have a 
strong theoretical base. He suggested two important theoretical relationships. Firstly, the internal structure and setting of organizations is of such a nature as to raise the probability that the attainment of the goals of the organization will subject the organization to the risk of violating societal laws of organizational behavior. Secondly, persons who actually act for the organization in the commission of crimes will, by selective processes, be associated with upward mobility in organizations, be likely to be highly committed to the organization and, for various reasons, be willing and able to carry out crime, should it seem to be required in order to enable the organization to attain its goals, to prosper, or at least, to survive.

Executives may sometimes argue that they need to commit crime because of criminogenic market forces. For example in some markets where corruption is the rule rather than exception, they need to pay bribes to enter into and stay in the market. This is in line with the theory of criminogenic market forces. Leonard and Weber (1970: 408) argue that too little attention has been paid to market forces as a reason for criminal behavior:

Insufficient attention has been focused by sociologists on the extent to which market structures - that is, the economic power available to certain corporations in concentrated industries - may generate criminal conduct.

Another example is price fixing cartels, which may seem to be the only way of sustaining manufacturing industries in high-cost regions.

Criminal behavior on behalf of the organization can be explained by the theory of monopoly. This theory is drawn from the area of organized crime. Financial crime often occurs as part of organized crime. Traditionally, a criminal organization is thought of as a monopolistic firm, and the theory of monopoly is predominantly used to analyze organized crimes. The monopolistic model implies that, upon deciding to commit a crime, potential criminals have no other choice but to join the criminal organization. Chang et al. (2005) find this perspective to be less than exhaustive in terms of describing criminal behavior. They argue that the determination of the market structure for crime should be endogenous, something which has notable implications for the optimal crime enforcement policies and crime itself.

To exhume the conventionally neglected facts and provide a more complete picture regarding organized crime, Chang et al. (2005) developed a model in terms of a criminal decision framework in which individual crime and organized crime are coexisting alternatives to a potential offender. The model makes the size of a criminal organization a variable and explores interactive relationships between varying sizes of criminal organization, the crime rate, and the government's law enforcement strategies. Model runs showed that the method adopted to allocate the criminal organization's payoffs and the extra benefit provided by the criminal organization play crucial roles in an individual's decision to commit a crime and the way in which he or she commits that crime.

\section{RESEARCH DESIGN AND SOME METHODOLOGICAL ISSUES}

To identify a substantial sample of white-collar criminals and to collect relevant information about each criminal, there are several options available. However, in a small country like Norway with a population of only five million people, there are limits to available sample size. One available option would be to study court cases involving whitecollar criminals. A challenge here would be to identify relevant laws and sentences that cover our definition not only of white-collar crime, but also required characteristics of white-collar 
criminals. Another available option is to study newspaper articles, where the journalists already have conducted some kind of selection of upper class, white-collar individuals convicted in court because of financial crime. Another advantage of this approach is that the cases are publicly known, which makes it more acceptable to identify cases by individual white-collar names. The selective and otherwise filtered information in newspapers might be a problem to other kinds of studies, but is considered an advantage in this study. Therefore, the latter option was chosen in this research. Kanskje også nevne at : The study is approved by NSD?

Based on this decision, our sample has the following characteristics as applied by newspapers when presenting news: famous individuals, famous companies, surprising stories, important events, substantial consequences, matters of principles and significant public interest. The sample consists of high profile and large yield offenses. This is in line with research by Schnatterly (2003) who searched the Wall Street Journal for several years in her study of white-collar crime published in the Strategic Management Journal.

There are two main financial newspapers in Norway, "Dagens Næringsliv" and "Finansavisen". In addition, the newspaper "Aftenposten" regularly brings news on whitecollar criminals. These three newspapers were studied on a daily basis from 2009 to 2012, i.e. three years, to identify white-collar criminals. A total of 255 white-collar criminals were identified during those years. A person was defined as a white-collar criminal if the person seemed to satisfy general criteria mentioned above, and if the person was sentenced in court to imprisonment.

It is important to keep in mind that our data is about newspaper accounts of white-collar crime, not the distribution of white-collar crime in society, because that is not what is being measured. Using a newspaper sample is different from the population of white-collar crime cases. We argue that newspaper account is one of the characteristics of white-collar crime as defined previously. Therefore, news reports are accurate reflections of knowledge about white-collar crime.

As suggested by Barak (2007), newsmaking criminology refers to the conscious efforts and activities of criminologists to interpret, influence or shape the representation of newsworthy items about crime and justice. Newsmaking criminology as a perspective on the theory, practice and representations of crime and justice is an important approach for understanding white-collar crime.

We make no distinction between prison and jail in this study. A prison or jail in Norway is a place in which people are physically confined and deprived of a range of personal freedoms. Imprisonment is a legal penalty that is imposed by the state for commission of a crime judged in court. In the United States, the difference between jail and prison is primarily a function of imprisonment length, where the use of prison over jail implies a more serious punishment.

Our operational definition of white-collar crime restricts the sample to those who receive jail time as punishment. This restriction excludes cases of fines as penal response, which is quite common. This sample restriction enables us to only study serious white-collar crime cases. Our intention is not to identify white-collar crime in reference to the law, but mainly with respect to the reporting of these offenses resulting in imprisonment. If the sample would be selected as references by the law, then a number of offenses would be defined in non-criminal statutes. Non-criminal statutes cannot, by their definition, result in jail time, only in civil remedies. Thus, by taking this view, we have essentially omitted most whitecollar crime cases from our study, since their severity is of a minor extent. Research articles 
edited by Gerber and Jensen (2006) suggest that only the most serious white-collar crime offenders end up in prison.

In our exploratory study it was considered sufficient that the person was sentenced in one court, even if the person represented a recent case that still had appeals pending for higher courts. A sentence was defined as jail sentence. Therefore, cases of fine sentence were not included in the sample. As our research is based on newspaper articles written by journalists, the reliability and completeness of such a source might be questioned. However, most cases were presented in several newspapers over several days, weeks or even months, enabling this research to correct for initial errors by journalists. Furthermore, court documents were obtained whenever there was doubt about the reliability of newspaper reports. This happened in one-third of reported cases.

It must be noted that there are, of course, disadvantages of applying newspapers as data source. According to Burns and Orrick (2002), research suggests that the media present a distorted image of crime by focusing on violent, sensational events that are atypical of crime in society. They argue that the media is neglecting coverage of corporate offenses, and that the media disproportionately focus on conventional crime while neglecting the impact of corporate misbehavior. This line of reasoning does not only acknowledge possible biases in our research. It can also be understood as an argument for our research design, where an important characteristic of our sample is that the white-collar crime cases stand out in the media.

Nevertheless, some types of corporate crime - probably those that are more typical may be still more neglected than other types of corporate crime. For instance, the media may be biased against small corporate offenses preferring larger offenses. Two methodological issues have to be kept in mind because of the newspaper decision:

- Bias because of press coverage. Financial crime committed by white-collar criminals is only exposed in the press to the extent that they are sensational and possibly revealed and discovered by the press itself. Therefore, no claim is made that the sample is a representative sample of white-collar criminals in general. Rather, there is a bias towards white-collar criminals that for some reason are of special interest to journalists and newspapers that cover their story. Therefore, the attribute of news coverage is explicitly added to the list of attributes for white-collar criminals including items such as position of trust, network and opportunity.

- Data errors in press coverage. Newspaper articles tend to have some errors in them. There may be factual errors, such as offender name, offender age, imprisonment sentence, crime type, and crime year. Furthermore, there may be disproportionate focus on sensational aspects of both criminal and crime. Everyone who has ever read about himself or herself in the newspaper will know that there are errors in the presentation. To reduce this source of error to a minimum, several newspaper stories of the same case were read and cited. Furthermore, court sentences were obtained in most of the cases to check both factual and story elements concerning both criminal and crime.

It must be noted that journalists in Norway enjoy respectability because of their integrity and seriousness. There are very few newspaper occupied with doubtful sensational stories. No such paper is found in our area of research into financial crime by white-collar criminals. Some journalists in the financial press have developed sophisticated skills in digging for criminal cases, where they apply robust and transparent methodologies. Every year in Norway, a prestigious prize is given to journalist(s) who have conducted an 
investigation and revealed news in a professional way. The prize is given to someone who both found a good story and did it in a respectable and professional way. The Norwegian journalism prize is called the SKUP award, and it is awarded by the Norwegian Foundation for a Free and Investigative Press. A newspaper sample suffers from severe selection bias that has to be taken into account when studying research results:

- Longer jail sentences than many other crime cases, since newspaper articles will disproportionately discuss more serious crime cases with longer sentences.

- Selecting crime cases with sentences instead of fines will also produce longer sentences in the data.

- The average amount involved in each crime case will be higher as newspaper articles will focus on more serious crime cases.

- Most crime cases were committed by a group as, again, newspaper articles are more likely to discuss these crime cases because conspiracies are more newsworthy than other individual crime cases.

- A significant number of criminals in high management positions will be present in the sample, again, because newspapers are more likely to discuss crime committed by higher-level employees.

- The size in terms of turnover and employees will be at the higher end, and the company will tend to be profitable, as crime against more successful companies is more likely to be newsworthy.

\section{CRIMINAL CHARACTERISTICS}

Criminal characteristics collected for each person included gender, age when convicted, age when committing crime, number of years in prison, court level, amount of money involved in crime, number of persons involved in crime, crime type, position level, personal income, person tax, personal wealth according to income statement, organization revenue, organization employees, private versus public sector, internal versus external detection, source of detection, corporate versus occupational crime, leader versus follower, and rotten apple versus rotten apple barrel.

Most white-collar criminals are men. This is confirmed in the sample of 255 persons, which included only 20 female criminals and 235 male criminals. Thus, less than 8 percent of the white-collar crime sample from newspaper articles was women - sometimes labeled pinkcollar criminals.

The youngest white-collar criminal in Norway was 21 years and the oldest was 77 years old. A distinction is made between age when convicted and age when committing crime. On average, a person was convicted 5 years after the crime, thus the average age when committing crime is 43 years old since the average age when convicted was 48 years old.

Most anecdotal cases, such as Rajaratman and Schilling, were men in their 50-ties or older. This is confirmed in our sample where the average age is 48 years old when convicted in court. These average numbers are similar to a study by Blickle et al. (2006) of 76 convicted German white-collar criminals. In their responding sample, there were 6 female criminals and 70 male criminals. The mean age of the offenders in Germany was 47 years.

The average jail sentence for 255 convicted white-collar criminals in Norwegian courts was 2.2 years, with a maximum of 10 years and a minimum of 15 days. The longest jail sentence of 10 years was given to a person involved in bank fraud, where millions were 
transferred from a rich widow's account in Norway to a friend's account in Dubai. Since the convicted criminal was operating in a group of criminals, he was convicted of organized crime, which in Norwegian law causes the jail sentence for a criminal act to be extended from a more normal level, say six years, to ten years in his case.

All persons in the sample received a jail sentence for white-collar crime. Compared to famous US cases mentioned above, these sentences are quite modest. However, in a Norwegian context these jail sentences are quite substantial, only passed by organized crime and murder. Also, when comparing to the sample used by Blickle et al. (2006) of white-collar criminals in Germany, there is no substantial difference, as the average was 3.9 years imprisonment in Germany in their sample of 76 convicts.

In the Norwegian court system, there are three levels: district courts, courts of appeal and Supreme Court. Out of 255 cases, 143 were decided final in district courts, 101 were decided final in courts of appeal, while 11 cases were decided final in Supreme Court.

The average amount involved in each financial crime case by white-collar criminals was 57 million Norwegian kroner. Since one US dollar is approximately six Norwegian kroner, this means on average 10 million US dollars. The smallest crime amount was less than 1 million, and the largest was 1200 million kroner.

57 white-collar criminals operated on their own when committing criminal acts. Most criminals involved others in the crime. On average, 4 persons were involved with each other in the white-collar crime cases studied. The maximum number involved in a case was 200 persons, where an accounting firm had been fixing 200 taxi owners' accounts so that they paid less tax. To avoid bias in statistics towards this case, only four persons from this taxi fraud scandal were included in our sample as white-collar criminals: the accounting responsible, the computer programmer, and two head taxi owners.

We define four main financial crime categories by white-collar offenders: fraud, theft, manipulation, and corruption. Fraud can be defined as intentional perversion of truth for the purpose of inducing another in reliance upon it to part with some valuable thing belonging to him or to surrender a legal right (Henning, 2009). Theft can be defined as the illegal taking of another person's, group's or organization's property without victim's consent (Hill, 2008). Manipulation can be defined as a means of gaining illegal control or influence over others' activities, means and results such as tax evasion (Malkawi and Haloush, 2008). Corruption can be defined as the giving, requesting, receiving or accepting of an improper advantage related to a position, office or assignment (Kayrak, 2008). In our sample of 255 convicted white-collar criminals, we find 131 cases of fraud, 12 cases of theft, 62 cases of manipulation, and 50 cases of corruption.

Consulting firm KPMG (2011) tried to identify characteristics of white-collar criminals who commit fraud. They found the following characteristics of the typical fraudster: Male, 36 to 45 years old, commits fraud against his own employer, works in the finance function or in a finance-related role, holds a senior management position, employed by the company for more than 10 years, and works in collusion with another perpetrator. These characteristics are based on 348 actual fraud investigations conducted by KPMG member firms in 69 countries.

We define three white-collar levels. The first level is owners of companies, board members of companies, and chief executive officers of companies. The second level is lawyers, consultants, investors, and brokers. The third level is middle managers, independent contractors and single-working individuals. In our sample of 255 convicted white-collar criminals, we find 76 individuals $(30 \%)$ at level 1, 106 individuals $(41 \%)$ at level 2, and 73 individuals (29\%) at level 3. 
Income figures for all taxable income are published annually by Norwegian tax authorities. Almost all 255 convicted white-collar criminals were found on the list for the year 2009. The average personal income was 327000 kroner (approximately 54000 US dollars), tax was 135000 kroner (approximately 22000 US dollars), and personal fortune was 6 million kroner (approximately 1 million US dollars).

White-collar offenders worked in an organization with revenues of 200 million kroner and 124 employees on average. 232 criminals worked in private sector organizations, while 23 criminals worked in public sector organizations.

The financial damage of 57 million Norwegian kroner was in most cases occurring outside the organization where the criminal worked. The victim of crime was typically another organization: 201 criminals caused damage to another organization or outside individual, while only 54 caused financial damage to his or her own organization. It is interesting to note that very few (23 criminals) worked in the public sector, while the victim of crime was very often found in the public sector.

\section{RESEARCH RESULTS}

In our criminal sample of 255 cases we find 88 corporate criminals and 167 occupational criminals. In the following table, we see that age when convicted was 47 years for occupational criminals and 49 years for corporate criminals, although this difference is not statistically significant. Similarly, nor are differences for age when the crime was committed and years in prison statistically significant, even though it is worth noting that occupational criminals served 2.2 years in prison, while corporate criminals served only 2.1 years. This is particularly interesting, when the next item on the list in the table is taken into account. It is concerned with the amount of money that was involved in the crime. While occupational criminals on average abused "only" 26 million Norwegian kroner, corporate criminals on average abused as much as 121 million Norwegian kroner. So, even if the magnitude of the financial crime in terms of money was substantially and significantly larger for corporate crime, occupational crime was nevertheless judged more severely in terms of imprisonment. Accordingly, corporate crime seems to pay compared to occupational crime!

The number of persons involved in financial crime is significantly different among the two groups. While 4.7 persons on average were involved in occupational crime, the average for corporate crime is 3.1 persons. This result may seem counterintuitive, as crime on behalf of the corporation would seem to need more involvement of others than is necessary for occupational crime. However, we have to remind our self that only convicted criminals are included in this sample.

The next item in the table is personal income of offender, although there is no statistically significant difference, in monetary terms the corporate criminal made more money than the occupational criminal. While making more money, the corporate criminal pays a little more money in tax to the government. However, corporate criminals are less wealthy than occupational criminals. In summary, based on a sample of 255 convicted whitecollar criminals in Norway, where 167 individuals were occupational criminals and 88 individuals were corporate criminals, we find some interesting differences between the two groups. In statistical terms, significant differences can be found in terms of crime amount and involved persons. Corporate criminals are involved in more severe crime when measured in the money amount involved, and corporate criminals involve fewer persons than occupational criminals. 
Another interesting aspect is the number of corporate criminals versus occupational criminals in the sample. There were 88 corporate and 167 occupational criminals, i.e. twice as many occupational criminals. This is in line with a survey in Norway by Gottschalk (2010) who had chief financial officers as respondents. Almost all responses in his survey implied that the respondents were thinking of occupational crime rather than corporate crime when responding to the following open-ended question: How will you proceed on suspicion of white-collar crime in your company? Only a few responses could be interpreted as being concerned with corporate crime, for example, where respondents would only discuss their suspicions with colleagues they trusted and where they would undertake controls and investigate before contacting outside experts.

Table 1. Comparison of characteristics of occupational crime versus corporate crime.

\begin{tabular}{|c|c|c|c|c|}
\hline Total 255 criminals & $\begin{array}{c}\mathbf{8 8} \text { corporate } \\
\text { criminals }\end{array}$ & $\begin{array}{c}\mathbf{1 6 7} \text { occupational } \\
\text { criminals }\end{array}$ & $\begin{array}{c}\text { T-statistic } \\
\text { difference }\end{array}$ & $\begin{array}{c}\text { Significance } \\
\text { of t-statistic }\end{array}$ \\
\hline Age convicted & 49 years & 47 years & 1.615 & .108 \\
\hline Age crime & 44 years & 42 years & 1.337 & .183 \\
\hline Years prison & 2.1 years & 2.2 years & -.270 & .787 \\
\hline Crime amount & 117 millions & 26 millions & 3.891 & .000 \\
\hline Involved individuals & 3.1 persons & 4.7 persons & -3.366 & .001 \\
\hline Personal income & 388000 kroner & 295000 kroner & 1.267 & .206 \\
\hline Personal tax & 165000 kroner & 120000 kroner & 1.543 & .124 \\
\hline Personal wealth & 1258000 kroner & 1499000 kroner & -.291 & .771 \\
\hline Business revenue & 217 millions & 191 millions & .518 & .605 \\
\hline Business employees & 145 persons & 113 persons & .829 & .408 \\
\hline
\end{tabular}

It is indeed possible to imagine that the number of persons involved in corporate crime is actually greater than 3.1 persons. The limited number can be explained by the theory of rotten apples. This theory argues that corporate crime is considered to be acts of individuals who represent rotten apples. According to this theory, involved persons are overlooked when criminals are prosecuted. Ashforth et al. (2008) argue that it is comforting to assume that one bad apple or renegade faction within an organization is somewhat responsible for the crime we too often observe. However, organizations are important to our understanding of crime, because they influence the actions of their members. Therefore, both micro and macro views are important to understand crime.

It is certainly an interesting issue whether to view white-collar misconduct and crime as acts of individuals perceived as 'rotten apples' or as an indication of systems failure in the 
company, the industry or the society as a whole. The perspective of occupational crime is favoring the individualistic model of deviance, which is a human failure model of misconduct and crime.

This rotten apple view of white-collar crime is a comfortable perspective to adopt for business organizations as it allows them to look no further than suspect individuals. It is only when other forms of group (O'Connor, 2005) and/or systemic (Punch, 2003) corruption and other kinds of crime erupt upon a business enterprise that a more critical look is taken of white-collar criminality. Furthermore, when serious misconduct occurs and is repeated, there seems to be a tendency to consider crime as a result of bad practice, lack of resources or mismanagement, rather than acts of criminals.

\section{DISCUSSION}

How was crime detected? Who detected crime? In this research, we searched the source of detection and found that journalists in the media investigated and revealed a total of 62 out of 255 white-collar criminals. This represents 24 percent, which means that one fourth of all white-collar crime was revealed by the press. However, there is a bias in our sample towards media sources, as only cases presented in the media are included. Nevertheless, it may seem surprising that journalists make such a significant contribution. After journalists we find victims of crime, who revealed 45 criminals (18\%):

1. Journalists: 62 criminals $(24 \%)$

2. Victims: 45 criminals (18\%)

3. Bankruptcy lawyers: $24(9 \%)$

4. Internal controls: 22 criminals $(9 \%)$

5. Auditors: 18 criminals $(7 \%)$

6. Tax authorities: 17 criminals $(7 \%)$

7. Banks: 14 criminals $(5 \%)$

8. Police: 10 criminals ( $4 \%$ )

9. Stock exchange: 5 criminals $(2 \%)$

10. Others: 38 criminals $(15 \%)$.

While it may seem surprising that journalists detected as many as 62 criminals (24\%), it may seem surprising as well that the police only detected 10 criminals (4\%).

A distinction can be made between leader and follower in crime. Followers tend to be naive and unaware of what is really happening, or they are simply taken in by the personal charisma of the leader and are intensely loyal to that person (Bucy et al., 2008). In our sample of 255 criminals, we find 140 leaders and 115 followers.

Another distinction is often made between corporate crime and occupational crime. While corporate crime is mainly for the benefit of the organization, occupational crime is mainly for the benefit of the individual (Hansen, 2009). In our 255 cases we find 88 corporate criminals and 167 occupational criminals.

The average jail sentence in Norway is 2.2 years, and 3.9 years in Germany (Blickle et al., 2006). In comparison, white-collar offenders in the United States have faced sentences that far exceed those imposed in previous years. For example, Bernard Ebbers, former CEO of WorldCom, was sentenced to twenty-five years; Jeffrey Skilling, former CEO of Enron, was sentenced to twenty-four years and four months; and Adelphia founder John Rigas received a sentence of fifteen years, along with his son Timothy Rigas, the CFO of the company, who received a twenty-year sentence. Podgor (2007) argues that these greatly 
increased sentences result in part from the application of the United States sentencing guidelines structure, which factors in the amount of fraud loss suffered in the computation of time. Although the sentencing guidelines have a degree of flexibility, resulting from the previously mentioned Supreme Court decision in United States v. Booker, the culture of mandated guidelines still permeates the structure and, as such, prominently influences the judiciary. Equally influential in such sentencing is the fact that as parole no longer exists in the federal system, the time given to these individuals is likely to closely correlate with the sentence that they will serve.

Despite short jail sentences, white-collar crime cases are taken seriously by the court system as well as the prison service. Also in the public, no excuses are accepted for their crime. When released from prison, very few are able to regain their positions in society: in terms of prestige, network and financial freedom. When asked what they found the worst consequence to be, whether media attention, duration of imprisonment, family collapse or financial ruin, answers differ. Many offenders seem to apply techniques based on neutralization theory (Siponen and Vance, 2010).

Jail sentences of 2.2 years on average for white-collar crime have to be compared to other kinds of crime. Murder is typically 9 years, drug smuggling 6 years, rape 4 years and child abuse 1 year.

\section{CONCLUSION}

In our criminal sample of 255 cases we find 88 corporate criminals and 167 occupational criminals. Age when convicted was 47 years for occupational criminals and 49 years for corporate criminals, although this difference is not statistically significant. Similarly, nor are differences for age when the crime was committed and years in prison statistically significant, even though it is worth noting that occupational criminals served 2.2 years in prison, while corporate criminals served only 2.1 years.

This is particularly interesting, when the amount of money that was involved in the crime. While occupational criminals on average abused "only" 26 million Norwegian kroner, corporate criminals on average abused as much as 121 million Norwegian kroner. So, even if the magnitude of the financial crime in terms of money was substantially and significantly larger for corporate crime, occupational crime was nevertheless judged more severely in terms of imprisonment.

Petter Gottschalk is professor of information systems and knowledge management in the department of leadership and organizational management at the Norwegian School of Management. Dr. Gottschalk has published several books and research articles on crime and policing. He has been the chief executive officer of ABB Datacables and Norwegian Computing Center.

Lars Glaso is professor of organizational psychology in the Department of Leadership and Organizational Behaviour at BI Norwegian Business School and adjunct professor in the Department of psychosocial science at the University of Bergen, Norway. Dr. Glasø is certified as clinical psychologist and specialist in applied organizational psychology. He has published extensively on issues such as workplace bullying, leadership and emotions in organisations. 


\section{References}

[1] Ashforth B. E., Gioia D. A., Robinson S. L., Trevino L. K., The Academy of Management Review 33(3) (2008) 670-684.

[2] Barak G., Theoretical Criminology 11(2) (2007) 191-207.

[3] Benson M. L., Simpson S. S., White-Collar Crime: An Opportunity Perspective, Criminology and Justice Series, Routledge, NY: New York, 2009.

[4] Blickle G., Schlegel A., Fassbender P., Klein U., Applied Psychology: An International Review 55(2) (2006) 220-233.

[5] Bookman Z., DePaul Business \& Commercial Law Journal 6 (2008) 347-392.

[6] Brightman H. J., (2009). Today's White-Collar Crime: Legal, Investigative, and Theoretical Perspectives, Routledge, Taylor \& Francis Group, NY: New York, 2009.

[7] Bucy P. H., Formby E. P., Raspanti M. S., Rooney K. E., St. John's Law Review 82 (2008) 401-571.

[8] Burns R. G., Orrick L., Critical Criminology 11 (2002) 137-150.

[9] Chang J. J. S., Journal of Financial Crime 15 (1) (2008) 71-81.

[10] Chang J. J., Lu H. C., Chen M., Economic Inquiry 43(3) (2005) 661-675.

[11] Dion M., Journal of Financial Crime 15(3) (2008) 308-319.

[12] Dion M., Journal of Financial Crime 16(4) (2009) 436-445.

[13] Dion M., Journal of Financial Crime 17 (2) (2010) 240-250.

[14] Eicher S., Government for Hire, in: Eicher, S. (editor), Corruption in International Business - The Challenge of Cultural and Legal Diversity, Corporate Social Responsibility Series, Gower Applied Business Research, Ashgate Publishing Limited, Farnham, England, 2009.

[15] Fleet D. D. van, Fleet E. W. van, Journal of Managerial Psychology 21(8) (2006) 763-774.

[16] Garoupa N., Journal of Economic Behavior \& Organization 63 (2007) 461-474.

[17] Gerber J., Jensen E. L., Encyclopedia of White-Collar Crime, Greenwood, Westport, Connecticut, 2006.

[18] Gottschalk P., (2010). White-Collar Crime - Detection, Prevention and Strategy in Business Enterprises, Universal-Publishers, Boca Raton, 2010.

[19] Gottschalk P., Glasø L., International Letters of Social and Humanistic Sciences 4 (2013) 22-34.

[20] Gross E., Studies in Symbolic Interaction 1 (1978) 55-85.

[21] Hansen L. L., Journal of Financial Crime 16(1) (2009) 28-40.

[22] Heath J., Journal of Business Ethics 83 (2008) 595-614.

[23] Henning J., Journal of Financial Crime 16(4) (2009) 295-304.

[24] Hill C., Journal of Financial Crime 15(4) (2008) 444-448. 
[25] Kayrak M., Journal of Financial Crime 15(1) (2008) 60-70.

[26] Kempa M., Journal of Financial Crime 17(2) (2010) 251-264.

[27] KPMG, KPMG Malaysia fraud survey report 2009. KPMG, Kuala Lumpur, Malaysia, 2009.

[28] KPMG (2011). Who is the typical fraudster? KPMG, www.kpmg.com.

[29] Leonard W. N., Weber M. G., Law \& Society Review 4(3) (1970) 407-424.

[30] Malkawi B. H., Haloush H. A., Journal of Financial Crime 15(3) (2008) 282-294.

[31] McKay R., Stevens C., Fratzi J., International Journal of Business Governance and Ethics 5(1) (2010) 14-25.

[32] Meneses R. A., Akers R. L., International Criminal Justice Review 21(4) (2011) 333-352.

[33] O'Connor T. R., (2005). Police Deviance and Ethics .In part of web cited, MegaLinks in Criminal Justice. http://faculty.ncwc.edu/toconnor/205/205lect11.htm, retrieved on 19 February 2009.

[34] Perri F. S., Brody R. G., Journal of Financial Crime 18(1) (2011) 93-104.

[35] Pickett K. H. S., Picket J. M., Financial Crime Investigation and Control. New York: John Wiley \& Sons, 2002.

[36] Podgor E. S., Journal of Criminal Law and Criminology 97(3) (2007) 1-10.

[37] Punch M., Policing and Society 13(2) (2003) 171-196.

[38] Robson R. A., American Business Law Journal 47(1) (2010) 109-144.

[39] Schnatterly K., Strategic Management Journal 24 (2003) 587-614.

[40] Simpson S. S., The Ohio State Journal of Criminal Law 8(2) (2011) 481-502.

[41] Siponen M., Vance A., MIS Quarterly 34(3) (2010) 487-502.

[42] Sutherland E. H., White collar crime, New York: Holt Rinehart and Winston, 1949. 